\title{
Pulau Bali dalam Pandangan Dunia Penyair Indonesia
}

\author{
Gita Safitri, Nurul Fitriani, dan Ninda Wahyuni \\ Universitas Muhammadiyah Malang \\ gigitasafitri@gmail.com \\ nurulfitriani039@gmail.com \\ ninday83@gmail.com
}

\begin{abstract}
Abstrak
Penelitian ini bertujuan untuk mengetahui bagaimana pandangan para penyair terhadap pulau Bali yang dituangkan dalam karyanya. Fokus penelitian ini adalah menyoroti pandangan dunia pengarang dalam menciptakan puisi tentang pulau Bali. Untuk mengupas tuntas hal tersebut digunakan teori strukturalisme genetik Lucien Goldmann. Teori ini digunakan sebagai upaya pengungkapan pandangan penyair terhadap kondisi masyarakat Bali yang nantinya dijadikan bahan imajinasi penyair. Sumber data yang digunakan dalam penelitian ini adalah kumpulan puisi dari empat penyair, yaitu WS Rendra Sajak Pulau Bali, Wayan Jengki Sunarta Selat Bali, Eka Budianta Pada Selembar Daun Gugur, dan Ketut Yuliarsa Hari Raya Pohon. Data yang digunakan berupa diksi-diksi bernilai estetik. Teknik pengumpulan data dengan cara studi dokumen. Hasil yang diperoleh dari penelitian ini adalah bahwa pengarang menggunakan sisi pandang yang berbeda-beda dalam mengambarkan pulau Bali. Pertama, WS Rendra menggunakan sisi pandang keburukan yang dimiliki Bali secara menyeluruh, mulai dari persoalan sosial hingga kebudayaan. Kedua, Wayan Jengki Sunarta mengunakan sisi pandang yang dimiliki Bali dengan titik fokus pada permasalahan sosial masyarakatnya. Ketiga, Eka Budianta menggunakan sisi pandang tragedi sejarah yang pernah terjadi di Bali. Keempat, Ketut Yuliarsa mengunakan sisi pandang kekayaan budaya yang dimiliki Bali.
\end{abstract}

Kata kunci: bali, pandangan dunia, peyair

\begin{abstract}
This research aims to acknowledge the poets perspective towards Bali in their writings. The focus of this research is to emphasize the creation of writings using Bali as a topic by the authors. To recognize the authors' views of Bali's society in their writings, Genetic structuralism theory by Lucien Goldmann is used. The data used as sources in this research including works from WS Rendra's Sajak Pulau Bali, Wayan Jengki Sunarta's Selat Bali, Eka Budianta's Pada Selembar Daun Gugur, and Hari Raya Pohon by Ketut Yuliarsa. Triangulation method is also used to check the validity of the data mentioned before. The result from this research is that writers use many different perspectives in portraying Bali in their writings. First, WS Rendra sees only the bad aspects of Bali, from social aspect to culture aspect. Second, Wayan Jengki Sunarta uses a perspective focusing on Bali's
\end{abstract}


problems in social aspect. Third, Eka Budianta takes Bali's tragedy in its history aspect. And fourth, Ketut Yuliarsa sees Bali as it is very rich in its culture.

Keywords: bali, world view, poet

\section{PENDAHULUAN}

Puisi merupakan suatu karya sastra yang tercipta dari ekspresi yang menggema dari kedalaman perenungan dan pengalaman hidup manusia yang tidak bertepi (Santoso, 2004:313). Oleh sebab itu semua orang bisa menciptakan puisi dengan berbagai inspirasi hasil dari perenungannya yang dipengaruhi oleh berbagai faktor, mulai dari faktor alam, sosial, religi, budaya dan sebagainya. Puisi sebagai karya sastra memiliki derajat yang lebih tinggi dibandingkan karya sastra lainnya karena puisi memiliki unsur kebahasaan yang indah. Keindahan dari puisi bisa dinikmati melalui penjiwaan kita sebagai pembaca.

Dalam suatu penciptaan sebuah puisi, penyair mendapat inspirasi melalui sense atau hubungannya dengan lingkungan secara langsung dalam arti penyair berhadapan, merasakan, dan berada dalam lingkungan. Selain itu lahirnya sebuah karya puisi dapat diperoleh dari interaksi secara tidak langsung, dengan memandang suatu keadaan lingkungan melalui perantara (Sugiarti \& Andalas, 2018: 14-16). Penyair melihat suatu keadaan sosial atau keadaan alam melalui sebuah media massa seperti surat kabar, majalah, radio, televisi, dan sebagainya. Melalui hal itu, penyair akan memilah- milah sumber inspirasi dari hasil pengamatannya yang sesuai pada waktu itu untuk dijadikan sebuah karya.
Seperti halnya dengan sosiologi, sastra berurusan dengan manusia dalam masyarakat, usaha manusia untuk menyesuaikan diri dan usahanya untuk mengubah masyarakat itu, yang dimana dapat dianggap sebagai usaha untuk menciptakan kembali dunia sosial, hubungan manusia dengan keluarganya, lingkungannya, politik, negara, dan sebagainya (Damono, 1978: 7; Andalas, 2017:21-23). Oleh karena itu, penyair memiliki cara tersendiri dalam mengungkapkan apa yang ada di lingkungannya.

Pengertian puisi tersebut setidaknya menyiratkan tiga hal: (1) puisi merupakan hasil imajinasi penyair. (2) puisi tercipta karena hasil perenungan penyair. (3) puisi merupakan produk dari apa yang ada dan yang terjadi di lingkungan penyair. Hal ini mengisyaratkan bahwa penyair merupakan anggota masyarakat yang tidak lepas dari pengaruh sosial serta budaya yang melatarinya. Penyair memandang lingkungan sekitar guna mengungkapkan keadaan sesungguhnya. Penyair akan menuangkan hasil perenungannya mengenai kondisi lingkungannya, salah satunya adalah pulau Bali.

Pulau Bali atau biasa dikenal dengan pulau Dewata merupakan daerah yang kaya akan budaya dan segala bentuk manifestasinya yang tidak luput dari pandangan penyair untuk diabadikannya 
dalam bentuk puisi. Berbagai macam kebudayaan ada di Bali sejak zaman dahulu hingga saat ini yang diwariskan secara turun temurun.

Seiring berkembembangnya zaman, perubahan serta pergesekan arus kebudayaan pada suatu lingkungan akan mengakibatkan tercipta atau terbuangnya suatu norma pada suatu masyarakat. Hal ini karena tiada masyarakat dan kebudayaan yang bersifat statis, maka dalam perspektif kultural, secara garis besar masyarakat dan kebudayaan lokal telah bergerak secara dinamis (Brata, 2016:10; Andalas, 2018:1). Melalui pernyataan pernyataan itu, dapat disimpulkan bahwa masyarakat akan meninggalkan apa yang telah dianggapnya tidak sesuai kebutuhan dan menggantinya dengan yang baru.

Hal ini dapat memicu turunnya nilai budaya yang berada di Bali yang berarti bahwa perubahan pada tataran nilai pada masyarakat Bali tidak dapat terelakkan. Ritzer (dalam Suwardani, 2015:249) menggambarkan bahwa perubahan nilai terjadi karena pengaruh (1) perpindahan orang, (2) media informasi, (3) teknologi yang dibawa atau yang dapat dilihat, (4) terjadinya aliran kepemilikan modal, dan

(5) ideologi- ideologi baik yang dibawa, diinformasikan, maupun yang dapat diadopsi.

Dari penjelasan diatas, dapat disimpulkan bahwa Bali adalah sebuah pulau yang memiliki kekayaan akan keindahan, kebudayaan, serta sumber dayanya yang melimpah. Setiap orang ketika mendengar nama Bali pemikiran yang terlintas adalah akan membayangkan betapa cantiknya pulau itu sebagai pulau wisata yang sangat terkenal di Indonesia maupun di dunia. Namun tak disangka pula bahwa Bali juga terdapat beberapa kekurangan, yang tidak lain adalah sisi kelam yang pernah terjadi dalam rentan masa lalu hingga saat ini dan hal tersebut belum diketahui oleh masyarakat pada umumnya.

Kekurangan maupun kelebihan tersebut mendapat perhatian dari kalangan penyair untuk dijadikan sumber inspirasi. Sampai sekarang, telah banyak karya-karya sastra puisi atau sajak tentang pulau Bali yang bermunculan, mulai dari penyair lokal asli Bali hingga penyair terkenal seperti Willibrordus Surendra Broto Rendra atau yang akrab dipanggil W.S Rendra. Melalui karyanya, W.S Rendra menggambarkan keadaan pulau Bali dengan puisinya yang berjudul Sajak Pulau Bali.

Puisi yang bertajuk Sajak Pulau Bali tersebut akan dijadikan objek kajian dalam penelitian ini bersamaan dengan puisi-puisi penyair terkenal lainnya seperti Wayan Jengki Sunarta, Eka Budianta, dan Ketut Yuliarsa. Penelitian ini penting dilakukan karena untuk menguak serta mengungkapkan kembali mengenai potret kehidupan pulau Bali dari segi sosial masyarakat dan budayanya serta sisi kelam atau kekurangannya yang belum diketahui masyarakat luas melalui sebuah karya puisi.

Sebelumnya, puisi Sajak Pulau Bali karya W.S Rendra pernah dikaji oleh Dian Cahyani (2015) dalam tesisnya yang berjudul Kolonialisme Industri Pariwisata di Bali dalam Puisi Sajak Pulau Bali karya WS Rendra (Kajian Poskolonial). Analisis tersebut meggambarkan bagaimana kondisi Indonesia setelah merdeka dilihat dari sudut 
Pulau Bali. Di mana space Bali yang dijadikan place industri pariwisata dan justru itu yang menjadikan Bali mengalami penjajahan karena keterlibatan negara- negara kaya dengan modal yang ditanamkannya pada industri dan hal ini membuat masyarakat pribumi kalah bersaing dan hanya menjadi budak.

Namun, yang dimaksud di sini, penulis mempaparkan bahawasanya sebagai bangsa Indonesia sama sekali bukan berarti mengabaikan keberadaan budaya asing dan keterlibatan dari manca negara tersebut, melainkan budaya asing tetap menjadi perhatian serta cerminan bagi rakyat indonesia dalam kapasitasnya demi pengembangan budaya khususnya Bali. Dikarenakan hal tersebut sangat penting demi keeksistensinya Pulau Bali. Seperti yang dikatakan Peursen (dalam Manuaba, 1999:57), "Tanpa dunia luar tidak ada pengalaman batin, kita tidak dapat berbicara mengenai makna dunia atau adanya". Dari kutipan tersebut dapat diartian pada masa kini masyarakat perlu mereposisi secara proporsional keberadaan budaya daerah yang beranekaragam itu dalam konteks budaya asing tanpa harus meninggalkan aspek eksistensi dari daerah itu sendiri.

Kemudian sehubungan dengan hal di atas perlu kiranya dipikirkan kembali apa yang akan dilakukan bangsa ini dalam menghadapi perubahan-perubahan yang berlangsung begitu cepat dalam masyarakat. Dalam artian nilai-nilai budaya lokal cukup relevan direvitalisasikan dalam menghadapi berbagai krisis konflik yang berdimensi sosial, ekonomi, budaya dan sebagainya, terkhususnya pada Pulau Bali itu sendiri (Brata, 2016:13).
Berbeda dengan penelitian yang telah dilakukan, penelitian ini secara khusus akan menyoroti bagaimana pandangan dari penyair lokal dan non lokal mengenai gambaran kehidupan pulau Bali yang dituangkan dalam karya puisi- puisinya. Selain itu, penelitian ini perlu dilakukan untuk melihat kondisi Bali dari sudut pandang penyair yang berbeda-beda. Karena pada dasarnya seorang penyair memiliki karakteristik dan ciri khas masing masing dalam merepresentasikan permasalahan yang ada di lingkungan sekitarnya melalui karyakaryanya.

Atas dasar permasalahan tersebut penelitian ini menggunakan pendekatan Sosiologi sastra serta teori strukuralisme genetik Lucien Goldman sebagai pisau bedah pengungkapan kondisi pulau Bali dalam lingkup sosial dan budaya melalui pandangan penyair. Pendekatan sosiologi sastra digunakan karena peneliti telah memperhatikan beberapa permasalahan yang terdiri dari pandangan para penyair akan perubahan budaya yang terjadi dalam ruang lingkup masyarakat tertentu. Hal ini sesuai dengan pernyataan Soekanto (2010:3) bahwa beberapa faktor yang menjadi pendorong utama ilmu sosiologi adalah meningkatnya perhatian terhadap kesejahteraan masyarakat dan perubahan- perubahan yang terjadi di dalam masyarakat.

Adapun manfaat teoritis dari penelitian ini adalah mampu menambah wawasan pengetahuan serta memberikan pola pandangan kepada teori sosiologi karya sastra dalam mengungkap perspektif penyair mengenai Bali. Secara praktis, penelitian ini juga diharapkan mampu memudahkan 
pembaca dalam mencari referensi penelitian karya sastra terutama lebih khususnya yang berhubungan dengan sosiologi karya sastra itu sendiri.

\section{METODE}

Dalam kajian ini digunakan jenis penelitian deskriptif kualitatif. Metode deskriptif kualitatif merupakan prosedur penelitian yang menghasilkan data deskripsi berupa kata tertulis atau lisan dari orangorang atau perilaku dengan tujuan memperoleh makna darinya (Andalas, 2017:188). Penelitian ini menggunakan deskripsi berupa kata-kata tertulis dan dalam penelitian ini informasi yang bersifat kualitatif dideskripsikan secara teliti dan analitis. Pendeskripsian meliputi perspektif pandangan dunia penyair, sepeti WS Rndra, Eka Budianta, Wayan Jengki Sunarta, dan Ketut Yuliarsa. Teknik pengumpulan data dilakukan dengan studi dokumen. Teknik analisis dengan 1) membaca, 2) menandai bagian-bagian penting, 3) menctat hasil yang telah ditandai, 4) menginterpretasikan data. Data dari pengkajian berwujud diksi yang bernilai estetik. Sumber data penelitian ini berupa puisi karya (1) W.S Rendra dengan judul Sajak Pulau Bali, (2) Wayan Jengki Sunarta dengan judul Selat Bali, (3) Eka Budianta dengan judul Pada Selembar Daun Gugur, dan (4) Ketut Yuliarsa dengan judul Hari Raya Pohon.

\section{HASIL DAN PEMBAHASAN}

Indonesia kaya akan kebudayaan yang dimiliki masing-masing daerahnya. Mulai dari ujung barat sampai ujung timur semuanya memiliki kebudayaan yang bereda-beda. Indahnya kebudayaan pada masing-masing daerah dapat dijadikan sebagai inspirasi oleh para penyair Indonesia yang dituangkan ke dalam karyanya. Seperti halnya WS Rendra, Eka Budianta, Wayan Jengki Sunarta dan Ketut Yuliarsa. Keempat penyair tersebut menggunakan pulau bali dalam menciptakan karya puisinya. Tentunya keempat penyair tersebut memiliki pandangan yang berbeda dalam menghasilkan karyanya. Pandangan mereka terhadap pulau Bali. Dalam penelitian ini, peneliti akan membahas bagaimana pandangan penyair lokal bali seperti Wayan Jengki Sunarta dan Ketut Yuliasa serta penyair non lokal bali seperti WS Rendra dan Eka Budianta dalam menghasilkan karyanya.

\section{Pandangan dunia WS Rendra dalam puisinya yang berjudul Sajak Pulau Bali}

Sajak Pulau Bali karya WS Rendra yang diciptakan pada tahun 1977 mengambarkan kondisi pulau Bali pada masanya. WS Rendra lahir di Solo, 7 November 1935. Perjalanan karirnya sebagai sastrawan tidak perlu diragukan lagi karna ia sudah banyak menghasilkan karya yang begitu banyak. Ia juga telah memperoleh berbagai penghargaan Nasional maupun Internasional. Dalam karyanya, Rendra banyak menyoriti permasalahan yang terjadi di masyarakat, baik di dalam negeri maupun di luar negeri.

Penelitian ini menggunakan salah satu karyanya yang berjudul Sajak Pulau Bali. 
Dalam Sajak Pulau Bali karyanya, rendra menuangkan persoalan yang tengah terjadi di Bali pada masa itu. Pada tahun 1977 Rendra menciptakan Sajak Pulau Bali di mana pada waktu itu kondisi pulau Bali masih begitu asri dan tidak sesak seperti sekarang. Dibuktikan dengan adanya penelitian yang menyatakan keadaan Bali pada waktu itu. Pada saat itu pariwisata merupakan bagian utama dari proses pembangunan yang dicanangkan Orde Baru. Wacana tentang orang asing sebagai ancaman tidak dimulai dari titik nol, melainkan berkembang dari antagonisme lama Sukarno dan PKI terhadap budaya populer barat sebagai aspek imperialisme (Adrian, 2013:6).

Dengan adanya wacana tersebut, masyarakat bali perlahan dibanjiri hasutan oleh sekelompok oknum-oknum yang ingin menguasai Bali. Di mana periode sebelum dimulainya pariwisata versi rencana Bank Dunia tampaknya bukan era dicekam kecemasan terhadap pengaruh asing yang jahat. Apakah yang dibayangkan orang Bali ketika membangun kembali pariwisata?

Pada kisaran tahun 70-an penulis dari Inggris menyatakan bahwa Akses ke Bali tidak mudah diperoleh. Tidak semua orang yang ingin bisa mendarat di sini, dan visa selain untuk transit jarang diberikan. Namun, menariknya buku tersebut dibumbui uraian tentang orang asing dari Eropa yang berlalulalang, dan pariwisata terus menerus muncul sebagai dekor kehidupan di Bali, dengan cara yang berusaha disangkal oleh banyak pustaka pra-perang (Adrian, 2013:13)

Identitas para pengusaha yang memulai kegiatan pariwisata era 70-an mulai menampakkan diri. Pembangunan hotel-hotel demi kenyamanan para wisatawan asing yang bermalam bahkan berhari-hari berada di Bali mulai marak terjadi. Terbukti dalam buku Soe Lie Piet yang berjudul Pengantar $\mathrm{Ke}$ Bali menceritakan tentang perkembangan Bali dari masa ke masa. Mulai dri pembangunan tempat wisata, hoter, restoran dan masih banyak lagi.

Dari peristiwa tersebut, Rendra mencerna dan mengamati setiap peristiwa yang terjadi di Bali melalui informasi publik seperti televisi, radio, koran maupun majalah. Rendra merupakan penyair non lokal Bali yang menggambarkan bali dengan pengetahuannya sebagai masyarakat Indonesia pada umumnya.

Persoalan lingkungan di Bali yang kala itu secara perlahan mulai dikuasai pihak asing. Rendra menggambarkan persoalan mulai dari lingkungan hingga kebudayaan yang dijadikan satu dalam sajaknya tersebut. Pertama, Rendra membahas persoalan Industri. Hal ini terbukti dalam kutipan sajaknya sebagai berikut:

\section{Sebab percaya akan keampuhan industri dan yakin bisa memupuk modal nasional dari kesenian dan keindahan alam, maka Bali mejadi obyek pariwisata. Sebab : \\ Pesawat-pesawat jet sudah dibikin, dan maskapai penerbangan harus berjalan.}

Dari kutipan sajak tersebut, pengarang mengambarkan keramaian pulau Bali yang dikunjungi oleh wisatawan dari berbagai penjuru dunia dapat memancing para pengusaha untuk saling berebut menyediakan maskapai penerbangan yang terbaik dan mejadikan beberapa titik wisata di Bali lebih menarik dan lebih baik dari sebelumnya 
sehingga memiliki nilai jual yang tinggi. Hal ini tergambar jelas bagaimana kondisi pulau Bali pada saat itu yang perlahan dikuasai oleh pihak asing. Menanamkan modalnya di Bali demi meraup keuntungan yang sebesarbesarnya. Kedua, dari sajaknya tersebut Rendra membahas persoalan kebudayaan masyarakat bali. Hal ini dibuktikan dengan kutipan sebagai berikut:

Dan Bali,

dengan segenap kesenian,

kebudayaan, dan alamnya,

harus bisa diringkaskan, untuk dibungkus dalam kertas kado, dan disuguhkan pada pelancong.

Kebudayaan rakyat ternoda digencet standar dagang internasional. Tari-tarian bukan lagi satu mantra, tetapi hanya sekedar tontonan hiburan. Pahatan dan ukiran bukan lagi ungkapan jiwa, tetapi hanya sekedar kerajinan tangan.

Kita semua mengetahui bahwa kebudayaan bali sudah mendunia. Itu artinya bahwa kebudayaan tersebut merupakan aset berharga yang harus dijaga dan dilestarikan keberadaannya.

Pada bait sajak tersebut, Rendra menyatakan keironisan keadaan pulau Bali dengan pemikiran bahwa pulau Bali yang memiliki kesenian, kebudayaan, dan keindahan alam hanya diringkas dan dikemas dengan penglihatan yang indah hanya untuk menarik perhatian para wisatawan. Semakin lama pulau Bali semakin banyak dikunjungi wisatawan dari berbagai negara. Hal tersebut merupakan suatu hal yang tidak terduga yang membawa pada goncangan kebudayaan.

Dari kutipan bait puisi diatas, memapaparkan bahwa setiap yang ada di Bali cenderung ditujukan untuk industri pariwisata, segenap kesenian seperti tari- tarian yang pada mulanya sakral menjadi hanya pertunjukan ataupun tontonan bagi pariwisata, kebudayaan bali yang unik, keindahan alam yang dijadikan lahan komersial.

Ketiga, Rendra membahas kesenjangan sosial yang terjadi pada masyarakat bali dan mengkritisi dampak dari segala sesuatu yang datang dari luar negeri untuk bangsa Indonesia. Hal ini terdapat dalam kutipan sajaknya sebagai berikut:

"Oh, look, honey - dear!

Lihat orang-orang pribumi itu!

Mereka memanjat pohon kelapa seperti kera.

Fantastic! Kita harus memotretnya!

Awas! Jangan dijabat tangannya! senyum saja and say hello.

You see, tangannya kotor

Siapa tahu ada telor cacing di situ.

My God, alangkah murninya mereka. Ia tidak menutupi teteknya!

Look, John, ini benar-benar tetek. Lihat yang ini! $O$, sempurna!

Mereka bebas dan spontan.

Pada kutipan tersebut, Rendra mengungkapkan fakta ironi pulau Bali bahwa pemandangan yang ada sebagai pulau yang diagung-agungkan oleh para orang kaya pada kenyataanya justru sebaliknya. Pada kenyataannya, di Bali masih banyak masyarakat pribumi yang hidup tertinggal dan hal ini memiliki citra yang tidak baik di mata para wisatawan. Pernyataan tersebut ditunjukkan dengan perilaku masyarakat 
pribumi yang memanjat pohon kelapa dan kurang mejaga kebersihan. Hal ini tergambar jelas dalam kutipan baitnya di atas.

Keempat, Rendra membahas mengenai ambisi manusia yang tiada henti. Di mana keinginan manusia yang secara terus menerus ingin saling menguasai apa yang ada di Bali. Hal ini tergambar dalam bait sajaknya sebagai berikut:

Tanpa menyimak jalannya
alam. Kekuasaan kemauan
manusia, Yang
dilembagakan dengan kuat,
Tidak mengacukan naluri
ginjal, Hati, empedu,
sungai, dan hutan. Di Bali:
Pantai, gunung, tempat tidur dan
pura, telah dicemarkan

Dari kutipan sajak di atas dapat kita uraikan bahwa ambisi manusia yang tidak ada hentinya. Keserakahan manusia yang terus memanfaatkan alam demi keuntungan individual maupun kelompok-kelompok tertentu demi memenuhi kebutuhan materialnya.

Hal ini sejalan dengan pernyataan Marx, bahwa pergulatan utama dan pertama manusia adalah pergulatan untuk memenuhi kebutuhan materialnya. Pergulatan itu membawa manusia berhadapan dengan alam sebagai sumber pemenuhan kebutuhan. Agar alam dapat menjadi sesuatu yang dapat memenuhi kebutuhannya, mausia dituntut untuk melakukan transformasi terhadap alam (Faruk, 2015:25). Oleh karena itu, tidak dapat dipungkiri bahwa hidup manusia bergantung pada alam. Namun perlu kita garis bawahi, bahwasanya alam juga membutuhkan kestabilannya untuk terus bisa memenuhi kebutuhan manusia. Jadi harus ada timbal balik antara hubungan manusia dengan alam.

Dari analisis keseluruhan sajak diatas, dapat disimpulkan bahwa penyair W.S Rendra mengupas persoalan yang tampak nyata terjadi sejak dahulu sampai saat ini. Jika dihubungkan dengan teori strukturalisme genetik Goldmann, maka dapat terlihat nyata. Di mana Rendra bukan bagian dari kelompok masyarakat Bali namun ia dapat menciptakan karyanya yang bertajuk Bali. Bahwa benar adanya pandangan dunia pengarang dalam teori strukturalisme genetik tidak hanya seperangkat gagasan abstrak dari suatu kelas mengenai kehidupan manusia dan dunia tempat manusia itu berada, melainkan juga sebuah pandangan yang menyeluruh dan terpadu mengenai hubungan antar manusia dan alam secara keseluruhan (Faruk, 2015:69)

\section{Puisi Selat Bali karya Wayan Jengki Sunarta}

Wayan Jengki Sunarta adalah tokoh sastrawan berkebangsaan Indonesia yang lahir pada tanggal 22 Juni 1975 di Denpasar, Bali. Namanya dikenal melalui sejumlah karyanya berupa novel, esai sastra, cerita pendek, dan puisi yang dipublikasikan di berbagai surat kabar.

$$
\text { Sebagai sastrawan yang }
$$
berdomisili Bali, Wayan sebagai penyair memandang keadaan sekitarnya melalui karya puisinya dengan judul Selat Bali, yang pada bagian awal menceritakan sisi kelam kehidupan nyata masyarakat Bali. Hal ini tertera pada kutipan puisi berikut:

di atas kapal usang ini 
kuserahkan diri

pada selat yang sempit

ombak tampak ramah angin serasa hangat

....

bocah-bocah penyelam

yang tubuhnya selegam kehidupan

berebut keping-keping uang logam

yang dilemparkan ke dalam lautan

ketangkasan mereka adalah hiburan

bagi penumpang yang cemas

Kutipan diatas menggambarkan bahwa dalam kehidupan masyarakat Bali masih mengalami kesusahan untuk memenuhi kehidupan sehari-hari. Demikian juga pada masyarakat yang masih tergolong usia muda sudah memiliki kewajiban untuk mencari sumber penghasilan dalam situasi dan kondisi apapun. Kegiatan yang sering berlangsung di Desa Gilimanuk mengalami sinar matahari yang sangat terik tiada hentinya. Terkadang pada pelabuhan Gilimanuk banyak sekali penumpang yang pingsan lantaran menunggu berjam- jam antrean di pelabuhan tersebut (Andini Raiza okezone: 2). Akan tetapi peristiwa tersebut tidak menghambat para penduduk sekitar khususnya anak- anak kecil yang menyambut bahagia para penumpang yang tengah berebut masuk ke dalam mulut kapal, sebab mereka tak lain adalah anak- anak pencari koin yang siap melompat dari atas kapal dengan senang hati. Dengan kegiatan tersebut justru menjadi sarana hiburan tersendiri bagi para penumpang di pelabuhan Gilimanuk.

Selain itu, pada bait selanjutnya penyair menceritakan tentang keadaan masyarakat Bali khususnya di Kawasan Gilimanuk dengan ditambahkan objek dan relasi yang sesuai dengan imajinasinya. Pernyataan tersebut dapat ditemukan dalam kutipan puisi sebagai berikut:

seorang preman menawariku jam tangan waktu senantiasa berdetik dalam jantungku lagu dangdut bajakan mengalun sendu tak mampu kutahan rindu daratan Gilimanuk makin samar kau entah di mana menyeberangi selat rambutmu masih terasa menyentuh pundakku

Dari kutipan bagian akhir diatas menjelaskan bahwa seolah-olah penyair berada diantara masyarakat. Berdasarkan daya imajinasi yang dimiliki, penyair menciptakan relasi dengan beberapa objek yang diungkapkan melalui sebuah karya puisi. Pernyataan ini terbukti pada kalimat kau entah dimana dengan kata ganti orang kau yang menduduki sebagai objek yang dibahas dalam puisi.

Hal ini sejalan dengan data yang dikemukakan (Istiqoma, dkk : 250) mengenai perubahan garis pantai Desa Gilimanuk yang seringkali mengalami perubahan yang tidak signifikan. Dimana pada tahun 2013 ke 2014 di beberapa titik garis pantai lebih banyak mengalami kemunduran (abrasi). Dalam artian perubahan garis pantai di desa Gilimanuk kerap kali terjadi perubahan garis pantai yang dinamis sehingga berdampak kepada para nelayan dan masyarakat yang sedang melakukan runtianitas seperti biasanya.

Dari hasil analisis puisi secara keseluruhan, dapat disimpulkan bahwa penyair memandang dari realitas kehidupan masyarakat asli pulau Bali dan menempatkan dirinya sebagai anggota kelompok masyarakat Bali yang dikelola dengan daya imajinatifnya. Hal ini searah dengan pendapat Goldmann dalam teori strukturalisme genetiknya 
mengenai pandangan dunia pengarang di mana sebagai suatu kesadaran kolektif, padangan dunia itu berkembang sebagai hasil dari situasi sosial dan ekonomi tertentu yang dihadapi oleh subjek kolektif yang memilikinya. Goldmann (dalam Faruk, 2015:66). Dari sini kita dapat mengetahui pandangan Wayan Jengki Sunarta menempatkan dirinya sebagai anggota kelompok masyarakat Bali memandang Pulau tanah kelahirannya masih mengalami masa buruknya dibalik kemegahan dan keindahan yang banyak diketahui orang luar. Hal ini disebabkan oleh arus ekonomi dan sosial pada masyarakatnya. Dibuktikan pada bait puisinya yang menyatakan:

bocah-bocah penyelam yang tubuhnya selegam kehidupan berebut keping-keping uang logam yang dilemparkan ke dalam lautan

Dari kutipan puisi tersebut kita dapat mengetahui bahwa pengarang memandang permasalahan terjadi akibat permasalahan sosial dan masyarakatnya memanfaatkan alam untuk memenuhi kebutuhan hidupnya. Jadi pengarang mengolah permasalahan tersebut yang kemudian dikembangkan dengan imajinasinya untuk menghasilkan karya tersebut.

\section{Puisi Pada Selembar Daun Gugur karya} Eka Budianta

Christophorus Apolinaris Eka Budianta atau lebih dikenal dengan sebutan Eka Budianta merupakan sastrawan asal Ngimbang, Jawa Timur. Karya puisinya yang berjudul Pada Selembar Daun Gugur mengisahkan tentang sejarah peristiwa kelam yang pernah terjadi di pulau Bali. Peristiwa itu tak lain adalah tragedi "Bom Bali 2". Hal ini terdapat dalam kutipan puisi di bawah:

\section{Pada selembar daun gugur yang pagi ini turun dari langit terbaca surat tertanggal 12 Oktober:}

\section{Saudara-saudariku tercinta} jangan bersedih

kami semua sudah sampai di Surga.

Kutipan diatas menggambarkan kejadian "Bom Bali 2" pada 12 Oktober 2005. Namun puisi ini tercipta setahun setelah peristiwa tersebut. Sebagai sastrawan yang bukan dari Bali, Eka Budianta mengambil sumber penciptaan karya puisinya dari kejadian "Bom Bali 2" dengan interaksi secara tidak langsung yaitu dengan cara mengamati melalui perantara lain. Sebuah karya puisi yang diciptakan tersebut juga merupakan wujud simpati dari peristiwa yang telah terjadi

Kutipan bait kedua di atas menggambarkan kesedihan masyarakat Bali terhadap korban. Momen yang menewaskan sekitar dua puluh tiga jiwa ini benar-benar peristiwa yang mengguncang, karena pada dasarnya, masyarakat di Bali saling menganggap kerabat sebagai saudara satu sama lain tanpa memandang agama, dan lainlain. Hal ini serupa dengan pernyataan yang dikemukakan oleh Suwitha dkk., (2018:129) bahwa kerukunan umat beragama di Bali sudah terjalin dengan baik dengan sistem budaya yang disebut nyama braya yang artinya saudara kerabat, saudara dekat sehingga teman- teman yang non-Hindu ataupun nonBali sudah dianggap sebagai kerabat. 
Selanjutnya pada dua bait berikutnya menjelaskan mengenai korban yang telah di doakan. Kutipan kedua bait tersebut adalah sebagai berikut:

Salam damai dari semua korban yang dengan tulus telah didoakan bersama burung dan bunga-bunga bersama ombak dan pasir pantai bersama dewa dan dewi yang memberkati pulau Bali.

Pada selembar daun gugur terbaca salam kasih dan pengampunan dari keluarga, saudara, dan teman yang telah menghapus air mata dalam duka dan penyesalan dalam persaudaraan sejati.

Pada kedua bait diatas, penyair ingin menyampaikan pesan bahwa korban telah meninggal dengan damai dan tentram karena sudah di doakan oleh masyarakat Bali. Dalam menghormati sesama manusia yang telah meninggal, masyarakat Bali yang sebagian besar beragama Hindu memiliki ritual doa tersendiri. Suwanthi dkk., (2018:131) berpendapat bahwa ada beberapa ajaran Hindu yang dipegang teguh oleh masyarakat Bali untuk hidup rukun dalam kehidupan bermasyarakat antara lain: Tatwam Asi, Atma Tattwa, Tri Kaya Prisudha, Tri Hita Karana, Vasundhaiva Kutumbakam, Sagilik- saguluk Salunglung Sabayantaka, Hukum Karma dan juga kearifan lokal menyama braya. (Suwitha dkk., 2018:131)

Terdapat tradisi upacara juga dilakukan pasca peristiwa Bom Bali, yaitu Pemlebeh Pemrayasita Durmanggala yang dilakukan pada enam hari setelah kejadian bom Bali yaitu pada Jumat 18 Oktober di jalan Legian Kuta, dan upacara Tawur Agung
Pamarisudha Karipubhaya, dengan tujuan untuk memohon ampunan untuk ketenangan para arwah korban, kedamaian dan kesejahteraan bagi masyarakat Bali (Suwitha dkk., 2018:131)

Dari analisis keseluruhan dari puisi diatas, dapat disimpulkan bahwa Eka Budianta ingin menyampaikan pesan kepada pembaca untuk memperingati peristiwa kelam tersebut tanpa adanya perasaan duka dan kedengkian yang berkelanjutan.

Pernyataan ini sejalan dengan pemikiran Goldmann bahwa teori strukturalismegenetiknya juga mengedepankan aspek kesejarahan lahirnya karya sastra (Endraswara, 2013:60). Di mana dalam menciptakan puisi tersebut pengarang menggali sejarah kelam yang pernah terjadi di Bali. Pengarang tidak akan bisa menciptakannya jika ia tidak mengetahui sejarahnya.

\section{Pandangan Dunia Ketut Yuliarsa terhadap} Bali dalam puisinya yang berjudul Hari Raya Pohon

Ketut Yuliarsa lahir di kota Denpasar pada tanggal 1 Januari 1960 merupakan sastrawan sekaligus penyair yang sekarang tinggal di wilayah Ubud, pulau Bali setelah menghabiskan waktunya untuk tinggal dan bekerja di Australia. Beberapa karya puisinya telah dicetak atau dipentaskan, salah satunya adalah puisinya yang berjudul Hari Raya Pohon.

Dalam menciptakan puisi Hari Raya Pohon pengarang terinspirasi dari alam sekitarnya dan juga latar belakangnya yang beragama Hindu. Karena puisi tersebut menceritakan adat budaya bali dalam ritual 
keagamaan. Masyarakat Bali pun mayoritas beragama Hindu karena memang secara historis, kultur yang dibangun di Bali lebih dominan ada dalam pengaruh agama Hindu (Deni, 2013:55). Oleh karena itu Ketut Yuliarsa menciptakan puisi Hari Raya Pohon sebagai bentuk aktualisasi diri kepada agama dan juga budaya Bali.

Puisi tersebut menceritakan tentang segala hal mengenai masyarakat pulau Bali dari sisi budaya dalam memperingati hari yang sakral di mana seluruh penduduk memberikan sesajian dan mengucapkan doadoa terhadap pohon-pohon yang dianggap keramat. Hal ini tergambar secara jelas dalam kutipan puisi sebagai berikut.

Aku bantu ibu ikat hiasan janur di batang pohon di celah cabangnya kita selipkan sajian bubur dengan piring lipatan daun.

Ini hari raya pohon, kita bersyukur atas jasanya beri makan untuk kita

“...ya kami haturkan sesaji bagi pohon semoga terus beranugerah kepada kami..." begitu doa ibu sambil percikan tirta dan dupa.

…

Aku percaya pohon itu punya arwah, berwatak dan berkepribadian.

Ada yang baik, murah hati, subur cepat berbunga dan berbuah

ada juga yang angker mengerikan semayaman makhluk gaib berbahaya tak boleh diganggu, minta ijin lewat disana

"Ya pohon... saya hanya numpang lewat, tidak bermaksud jahat, mohon selamat... AUM..."

Begitu mantranya.

Dari kutipan bait pertama digambarkan bahwa saat hari raya pohon masyarakat Bali yang memperingati akan menyiapkan beberapa sajian berupa beberapa wujud makanan sebagai tanda syukur karena telah diberi rezeki yang melimpah. Dalam bait ini juga digambarkan mengenai langkah-langkah saat melakukan ritual sesajian dengan memercikkan air dan dupa sambil merapalkan doa-doa.

Selanjutnya, dalam bait kedua menerangkan tentang kepercayaan masyarakat Bali terhadap kesakralan pohon-pohon disekitarnya yang sudah berusia tua sekali sehingga pohon-pohon tersebut dianggap memiliki arwah yang bermacam-macam. Kemudian pada bait terakhir menceritakan mengenai arwah pohon-pohon yang telah tumbang seperti pada kutipan dibawah ini.

Pohon tumbang arwah mereka
gentanyangan
Mencari celah untuk lahir dan tumbuh
kembali.
Tapi tanah sudah habis disita manusia,
bangunan sesak berjejal, sampah
bertumpuk wabah menyerang dunia
berperang
tumpahan darah korban mengalir dan
mengendap
melapuk akhirnya lumatmerabuk.

Kutipan di atas memiliki pesan yang dalam dengan digambarkan mengenai keadaan pulau Bali yang dengan seiringnya waktu berjalan sudah beranjak hilang dari kemurnian dan keindahannya. Pada keadaan saat ini pulau Bali terdapat bangunanbangunan yang banyak dan sudah ternoda dari keasliannya, begitupun mengenai beberapa tragedi pertumpahan darah yang sempat terjadi.

Dalam puisi ini, dapat dirangkum penyair memandang masyarakat Bali 
memiliki tradisi dan kebudayaan yang beragam. Bahwasanya kebudayaan sebagai kompleks pengetahuan, maka budaya harus dipelajari secara terus menerus dalam kehidupan seorang individu untuk tujuan tertentu (Biyas, 2013:240). Untuk itu masyarakat Bali yang kental dengan budaya yang dijadikannya sebagai citra daerah. Kebudayaan Bali yang erat kaitannya dengan religiusitas salah satunya seperti peringatan hari raya pohon yang tergambar dalam puisi ini. Sama seperti ketiga penyair sebelumnya, Ketut Yuliarsa juga menggambarkan pandangannya terhadap keadaan pulau Bali saat ini yang sudah mulai hilang dari keasliannya. Namun dengan menghadapi persoalan itu, penyair menyampaikan pula sebuah pesan kepada masyarakat bahwa meskipun Bali sudah tidak seperti dulu yang keasrian dan kemurniannya tetap terjaga, masyarakat harus bersikap positif dan selalu menjalankan yang terbaik agar kebaikan akan tetap terus berlanjut di masa depan. Hal ini tertera dalam kutipan bait puisi berikut:

\section{Tapi itu justru baik membina kesuburan benih hidup baru yang akan berderajat lebih tinggi lagi, kata ibu.}

Pesan dan analisis puisi diatas secara keseluruhan memiliki hubungan yang sama seperti teori Luciel Goldmann dengan teori strukturalisme-genetiknya mengenai subjek kolektif. Dalam karya sastra terdapat subjek trans-individual. Subjek yang demikianlah yang juga menjadi subjek karya sastra yang besar sebab karya sastra semacam itu merupakan hasil aktifitas yang objeknya sekaligus alam semesta dan kelompok manusia (Goldmann dalam Faruk 1999: 15). Berbagai pandangan tersebut memperlihatkan bahwa karya sastra tidak hanya memenuhi fungsi estetis semata, tetapi terdapat pesan ideologis yang menjadi tanggung jawab moral di dalamnya (Andalas, 2018:100).

\section{KESIMPULAN}

Berdasarkan identifikasi yang dilakukan terhadap pandangan para penyair mengenai pulau Bali terdapat empat penyair yaitu WS Rendra dengan Sajak Pulau Bali, Wayan Jengki Sunarta dengan Puisi Selat Bali, Eka Budianta dengan Puisinya yang berjudul Pada Selembar Daun Gugur, dan Ketut Yuliarsa dengan puisinya yang berjudul Hari Raya Pohon. Dari keempat penyair tersebut, keempat- empatnya memiliki pandangan yang berbeda dalam mengambarkan pulau Bali.

Pertama WS Rendra memandang bahwa keadaan pulau Bali pada waktu itu sudah mulai menampakkan dirinya sebagai tempat pariwisata berskala besar pada era Sukarno denga merangkul pihak pebisnis luar negeri. Hal ini seakan menindas masyarakat Bali kala itu yang masih asri dari kemoderenan. Kekhawatiran Rendra kala itu akan keadaan pulau Bali kedepannya digambarkan olehnya melalui sajaknya tersebut. Rendra melihat semua permasalahn itu dari kacamata luar dirinya karena bukan masyarakat asli Bali. Namun hal itu tidak membatasinya untuk menciptkan sebuah karya yang menggambarkan kondisi lingkungan yang jauh darinya. Rendra memandang pulau Bali dari sisi buruk dan baiknya yang dikolaborasikan dengan daya imajinatif dan kreatifnya yang kemudian memunculkan 
Sajak Pulau Bali .

Kemudian Wayan Jengki Sunarta. Penyair asli Bali yang menggunakan pandangannya sebagai anggota kelompok masyarakat asli bali dan mengetahui selukbeluk lingkunganya tersebut lebih menitik beratkan pada kondisi sosial masyarakatnya di daerah pinggiran. Ia ingin menunjukkan bahwa dibalik kekayaan yang dimiliki pulaunya tersebut masih banyak rakyatnya yang tidak bisa menikmatinya dengan leluasa karena kalah dengan orang asing. Selanjutnya Eka Budianta, penyair yang sama dengan WS Rendra. Ia bukan bagian dari anggota masyarakat Bali. Meskipun begitu, ia menggunakan pengetahuan sejarah terjadinya tragedi kelam yang dialami Bali. Eka lebih menyoroti masalalu yang kelam tersebut. Diciptakannya puisi Pada Selembar Daun Gugur sebagai ungkapan simpatinya terhadap masyarakat Bali kala itu dengan tidak menjadikannya sebagai alasan untuk berlarut dalam kesedihan. Dan yang terakhir Ketut Yuliarsa yang merupakan bagian dari anggota kelompok masyarakat bali seperti Wayan Jengki Sunarta. Ketut Yuliarsa mengunakan pandangannya dari sisi kebudayaan. Dengan tujuan untuk memperkenalkan ritual yang sesunguhnya pada khalayak umum. Kebudayaan yang sudah ada sejak jaman dahulu sampai saat ini. Dan hal ini merupakan bagian dari keindahan Bali.

Jadi pada dasarnya keempat penyair tersebut menggunakan pandangan yang berbeda dalam memperlihatkan Bali. Dari berbagai sisi, WS Rendra, Wayan Jengki Sunarta, dan Eka Budianta menguak dari sisi buruk yang dimiliki Bali. Sedangkan dengan Ketut Yuliarsa mengupas Bali dari sisi Keindahannya. Karena seorang penyair akan menggunakan berbagai pandangan dalam menghasilkan sebuah karya, namun tetap tidak meninggalkan struktur karya sastra dengan struktur masyarakatnya serta alam semesta.

\section{DAFTAR PUSTAKA}

Andalas, E. F. (2017). Dampak dan Fungsi Sosial Mitos Mbah Bajing bagi Kehidupan Spiritual Masyarakat Dusun Kecopokan Kabupaten Malang Jawa Timur. Puitika, 13(1), 21-31.

Andalas, E. F. (2017). Eskapisme Realitas dalam Dualisme Dunia Alice: Telaah Psikologi-Sastra FIlm Alice in Wonderland (2010). Kembara, 3(2), 185-195.

Andalas, E. F. (2018). Cerita Rakyat dan Tradisi Masyarakat Agraris Nusantara: Mitos Dewi Sri (Jawa) dan Legenda Putri Mandalika (Sasak). In P. Karyanto (Ed.), Kisah-Kisah Perempuan dan Cerita Rakyat Nusantara (pp. 1-12). Surabaya: Kajian Sastra dan Budaya Universitas Airlangga.

Brata, I. B. (2016). Kearifan Budaya Lokal Perekat Identitas Bangsa. Jurnal Bakti Saraswati, 10-13.

Bungin, B. (2007). Penelitian Kualitatif, Komunikasi, Ekonomi, Kebijakan Publik, dan Ilmu Sosial Lainnya. Jakarta: Kencana Prenada Group.

Damono, S. D. (1978). Sosiologi Sastra: Sebuah Pengantar Ringkas. Jakarta: Pusat Pembinaan dan Pengembangan Bahasa Departemen Pendidikan dan Kebudayaan. 
Endraswara, D. S. (2013). Metodologi Penelitian Sastra. Yogyakarta: Center for Academic Publishing Service.

Faruk, D. (1999). Pengantar Sosiologi Sastra. Yogyakarta: Pustaka Pelajar .

Faruk, D. (2015). Pengantar Sosiologi Sastra dari Strukturalisme Genetik sampai Post-modern. Yogyakarta: Pustaka Pelajar.

Jalil, D. A. (1990). Teori dan Periodesasi Puisi Indonesia. Bandung: Angkasa.

Malik, F. (2016). Peranan Kebudayaan dalam Pencitraan Pariwisata Bali. Jurnal Kepariwisataan Indonesia, 69.

Manuaba, P. (1999). Budaya Daerah dan Jatidiri Bangsa: Pemberdayaan Cerita Rakyat dalam Memasuki Otonomi Daerah dan Globalisasi,". Masyarakat, Kebudayaan dan Politik, 57-66.

Miharja, D. (2013). Adat, Budaya dan Agama Lokal Studi Gerakan Ajeg Bali Agama Hindu Bali. Jurnal Studi Agama dan Pemikiran Islam, 53-78.

Santoso, T. (2004). Kajian Sosio Budaya Kumpulan Sajak Madura "Akulah Darahmu" Karya D. Zawawi Imron. Humaniora, 313.

Sapulette, E. M. (2014). Pandangan Dunia Pengarang dalam Novel Nak, Maafkan Ibu Tak Mampu Menyekolahkanmu Karya Wiwid Prasetyo (Kajian Strukturalisme Genetik Lucien Goldmann). Jurnal Pendidikan, 42-45.

Soekanto, S. (2010). Sosiologi Suatu Pengantar. Jakarta: Rajawali Pers.

Sugiarti, \& Andalas, E. F. (2018). Perspektif Etik dalam Penelitian Sastra. Malang: UMM Press.
Sukarya, E. B. (2007). The Poetry of Nature. Jakarta: PT. Sukarya \& Sukarya Pandetama.

Suwardani, N. P. (2015). Pewarisan Nilainilai Kearifan Lokal untuk Memproteksi Masyarakat Bali dari Dampak Negatif Globalisasi. Jurnal Kajian Bali, 248-249.

Suwitha, D. S. (2012). Dinamika Kerukunan Antar Umat Beragama. Jurnal Humanis, 127-132.

Vickers, A. (2013). Bali Membangun kembali Industri Pariwisata. Jurnal Kajian Bali, $1-38$.

Wihantari, B. (2013). Studi Etnografi Penanaman Nilai Agama Hindu pada Anak. Jurnal Antropologi, 238-254. 